\title{
Pilferer, murderer of innocents or prey? The potential impact of killer shrimp (Dikerogammarus villosus) on crayfish
}

\author{
Sara Roje ${ }^{1}$ Kateřina Švagrová ${ }^{~} \cdot$ Lukáš Veselý $^{1} \cdot$ Arnaud Sentis $^{2} \cdot$ Antonín Kouba $^{1} \cdot$ Miloš Buřič $^{1}$ (i)
}

Received: 21 April 2020 / Accepted: 6 October 2020 / Published online: 15 October 2020

(c) The Author(s) 2020

\begin{abstract}
Freshwater ecosystems worldwide are facing the establishment of non-native species, which, in certain cases, exhibit invasive characteristics. The impacts of invaders on native communities are often detrimental, yet, the number and spread of non-native invasive species is increasing. This is resulting in novel and often unexpected combinations of non-native and native species in natural communities. While the impact of invaders on native species is increasingly well-documented, the interactions of non-native invaders with other non-native invaders are less studied. We assessed the potential of an invasive amphipod, the killer shrimp Dikerogammarus villosus (Sowinsky, 1894), to cope with other established invaders in European waters: North American crayfish of the Astacidae family-represented by signal crayfish Pacifastacus leniusculus (Dana, 1852), and the Cambaridae family—represented by marbled crayfish Procambarus virginalis Lyko, 2017. The main goal of this study was to investigate if killer shrimp, besides their role as prey of crayfish, can significantly influence their stocks by predating upon their eggs, hatchlings and free-moving early juveniles. Our results confirmed that killer shrimp can predate on crayfish eggs and hatchlings even directly from females abdomens where they are incubated and protected. As marbled crayfish have smaller and thinner egg shells as well as smaller juveniles than signal crayfish, they were more predated upon by killer shrimp than were signal crayfish. These results confirmed that the invasive killer shrimp can feed on different developmental stages of larger freshwater crustaceans and possibly other aquatic organisms.
\end{abstract}

Keywords Freshwater $\cdot$ Crustacea $\cdot$ Amphipod $\cdot$ Invasive species $\cdot$ Interaction $\cdot$ Predation

\section{Introduction}

Crustaceans play an important role as prey and consumers in aquatic ecosystems, transferring energy from lower to higher trophic levels. However they are also very successful invaders and the increased introduction, establishment and dispersal of non-native crustaceans in Europe has the potential to wreak havoc on freshwater foodwebs (Strayer 2010; Hänfling et al. 2011). They play an irreplaceable role in food chains, both as prey and as consumers transferring energy from lower to higher trophic levels (MacNeil et al. 1997;

Miloš Buřič

buric@frov.jcu.cz

1 Faculty of Fisheries and Protection of Waters, South Bohemian Research Center of Aquaculture and Biodiversity of Hydrocenoses, University of South Bohemia in České Budejovice, Zátiší 728/II, 38925 Vodňany, Czech Republic

2 INRAE, Aix Marseille Univ., UMR RECOVER, 3275 route Cézanne, 13182 Aix-en-Provence, France
Dorn and Wojdak 2004; Väinölä et al. 2008; Lodge et al. 2012). In Europe, there are many native species of freshwater crustaceans, but the last decades have seen the increased introduction, establishment and dispersal of non-native crustacean species (Gherardi 2007). Many of these alien species have become invasive pests, even more frequently than usually hypothesised (Jeschke and Strayer 2005; Jeschke 2008), and their occurrence threatens native biota (Ricciardi et al. 2017; Jeschke and Heger 2018).

Freshwater ecosystems, especially large rivers, are increasingly subject to multiple invasions where several groups of invasive alien species (IAS) occur simultaneously in space and time (Gebauer et al. 2018). They compete for space, food, predate on natives and can sometimes transmit diseases and parasites (Ricciardi et al. 2011; Jeschke and Heger 2018). Increased spread of IAS in European waters results not only in contact and competition among native and non-native invasive species, but also among invaders from different biogeographic regions (Ricciardi et al. 2011). In addition, the presence of invasive species in an ecosystem 
can facilitate invasion by other species (invasional meltdown hypothesis), and increase the likelihood of their survival and negative ecological impacts (Simberloff 2006). Their effects on ecosystems can be divergent but simultaneously additive or even multiple. One way or another, IAS can inhibit, displace or even eradicate each other (Ricciardi and Atkinson 2004).

Decapods and amphipods are particularly successful and diverse orders of crustaceans, especially the non-native representatives of these groups in Europe (Gherardi 2007; Hänfling et al. 2011). Crayfish are the most abundant decapod invaders in European freshwaters, with at least eleven non-native species (Kouba et al. 2014; Weiperth et al. 2017). The vast majority of these species are classed as invasive, especially those originating from North America (Holdich et al. 2009; Kouba et al. 2014). They are characterized by the ability to withstand extreme conditions (Haubrock et al. 2019; Veselý et al. 2015), high fecundity, aggressiveness, activity, fast maturation, high population densities and/or the ability to transmit diseases deadly to native crayfish (Buřič et al. 2013; Kotovska et al. 2016; Svoboda et al. 2017; Vodovsky et al. 2017). In amphipods, species originating from the Ponto-Caspian basin are the most problematic IAS of the main river catchments across Europe (Bij de Vaate et al. 2002). In general, species of the genus Dikerogammarus, with the flag bearer species D. villosus (Sowinsky, 1894) known as the killer shrimp, are the most reported invasive amphipods in European freshwaters (Bij de Vaate et al. 2002; Pöckl 2009; Rewicz et al. 2014). Killer shrimp is a voracious predator, preying on a wide spectrum of benthic macroinvertebrates including insect larvae, leeches, isopods, other amphipods, and juvenile crayfish (Krisp and Maier 2005; Buřrič et al. 2009; Boets et al. 2010; Rewicz et al. 2014). Predation on fish eggs is also reported (Taylor and Dunn 2017). Moreover, killer shrimp have been observed injuring or even killing other macroinvertebrates without consuming them, which illustrates their aggressive nature and potential impact on prey populations (Dick and Platvoet 2000).

Killer shrimp often co-exist and interact with several invasive crayfish species, e.g. the signal crayfish Pacifastacus leniusculus (Dana, 1852) and the spiny-cheek crayfish Faxonius limosus (Rafinesque, 1817), representatives of the families Astacidae and Cambaridae (Gherardi 2007). Killer shrimp have been observed predating on early independent crayfish juveniles (Buřič et al. 2009), but their impact on other life stages remains unclear. Thus in our present study, we hypothesized a negative impact of killer shrimp on different developmental stages of crayfish (eggs, hatchlings, first independent stage of juveniles) even those actively protected by mothers. Species in the family Astacidae, such as the signal crayfish and native European noble crayfish Astacus astacus (Linnaeus, 1758), typically have larger eggs and early developmental stages (Kozák et al. 2009; Kouba et al. 2010), while species in Cambaridae, such as the clonal marbled crayfish Procambarus virginalis Lyko, 2017, are small bodied crayfish with smaller eggs and smaller juveniles (Kouba et al. 2014; Patoka et al. 2016). This study will elucidate if small amphipods like killer shrimp can negatively affect populations of larger decapods (including both mentioned families) via predation on their actively protected early developmental stages.

\section{Materials and methods}

\section{Animals acquisition and maintenance}

\section{Killer shrimp}

Killer shrimp adults were collected at the lower reaches of the Czech section of the River Elbe (coordinates: $50.655 \mathrm{~N}$, 14.043 E) from shallow rocky habitats in April 2015. Individuals were hand collected by walking upstream and turning over stones, shaking the bottom substrate and using hand nets to capture individuals escaping or carried by the water flow. Killer shrimps were transported in polyethylene bags with water to the experimental facility of the Research Institute of Fish Culture and Hydrobiology (RIFCH) in Vodňany, where they were identified to species level using morphological characters (Eggers and Martens 2001) and acclimated to laboratory conditions before beginning the experiment. Killer shrimps were placed individually in $100 \mathrm{ml}$ boxes half-filled with aged tap water. Water was exchanged daily and killer shrimps were fed once per day with one chironomid larvae, except on the day prior to the start of the experiment. The mean body weight of killer shrimps used in the experiments is reported below.

\section{Marbled crayfish}

Marbled crayfish was used as a suitable model species comparable with other cambarids (Hossain et al. 2018) like spiny-cheek crayfish or calico crayfish Faxonius immunis (Hagen, 1870) which are known to co-occur with killer shrimp in European rivers. Marbled crayfish were obtained from our own experimental culture held at RIFCH. Females with attached eggs were selected from the culture stock and held individually to avoid interference by other crayfish. They were acclimated to laboratory conditions in $2500 \mathrm{ml}$ plastic boxes with $2000 \mathrm{ml}$ of aged tap water at $20^{\circ} \mathrm{C}$ before the experiments. The temperature was maintained by storing the boxes in an adjustable temperature incubator with $12 \mathrm{~h}$ 
light and $12 \mathrm{~h}$ dark photoperiod. The females were used in four different ways:

1. 38 females (carapace length, $\mathrm{CL}=22.7 \pm 4.0 \mathrm{~mm}$, measured from the tip of rostrum to the posterior edge of cephalothorax, weight $=4.3 \pm 2.5 \mathrm{~g}$ ) were stripped of eggs to estimate fecundity. Eggs were carefully stripped firstly from the 3rd pair of pleopods using entomological forceps and placed in a Petri dish with a small amount of water and counted. Then, the rest of attached eggs were stripped to another Petri dish with a small amount of water and counted. Data obtained were used in a regression analysis to obtain an equation for linear regression to estimate total fecundity from eggs sampled from the 3rd pair of pleopods (as recommended by Hossain et al. 2019).

The eggs were then used to test the ability of killer shrimp to destroy and eat marbled crayfish eggs (see below). The sample of 50 eggs was weighed using an analytical scale (Mettler, Toledo, USA) to the nearest $0.1 \mathrm{mg}$ to calculate average egg weight $(2.4 \mathrm{mg})$. The rest of the eggs were terminated by hot water and discarded.

2. 16 ovigerous females $(C L=25.2 \pm 4.3 \mathrm{~mm}$, weight $=5.7 \pm 3.6 \mathrm{~g}$ ) were used to test the ability of killer shrimp to destroy and eat marbled crayfish eggs directly from the female's pleopods in spite of maternal care and protection. Prior to the experiment, all eggs from the 3rd pair of pleopods were carefully stripped from each female using entomological forceps and counted to estimate initial total fecundity.

3. 25 ovigerous females $(\mathrm{CL}=24.3 \pm 3.9 \mathrm{~mm}$, weight $=5.3 \pm 2.6 \mathrm{~g}$ ) were incubated until hatched juveniles reached the 3rd developmental stage (DS) - the stage of independence in cambarid crayfish (Andrews 1907; Vogt et al. 2004). Juveniles were carefully detached using entomological forceps and then used to test the ability of killer shrimp to overpower and eat marbled crayfish early juveniles. The sample of 50 juveniles was individually weighed using an analytical scale (Mettler, Toledo, USA) to the nearest $0.1 \mathrm{mg}$ to calculate the average individual weight $(3.9 \pm 0.6 \mathrm{mg})$.

4. For the last experiment, 70 randomly selected mature marbled crayfish $(\mathrm{CL}=22.6 \pm 2.8 \mathrm{~mm}$, weight $=3.4 \pm 1.3 \mathrm{~g}$ ) were taken from our own culture and maintained in the same way as ovigerous females. These were used to assess marbled crayfish predation on mature killer shrimp individuals.

\section{Signal crayfish}

Signal crayfish were caught in April 2015 from the pond system near Velké Meziříčí (49.379 N, 16.082 E) using baited traps. After transfer to the experimental facility of RIFCH, they were placed into flow through channels. Female crayfish with attached eggs were sorted and held individually to avoid interference by other crayfish. These females were acclimated to laboratory conditions in $2500 \mathrm{ml}$ plastic boxes with $2000 \mathrm{ml}$ of tap aged water at $15{ }^{\circ} \mathrm{C}$ before the experiments. The temperature was maintained by storing the boxes in an adjustable temperature incubator with $12 \mathrm{~h}$ light and $12 \mathrm{~h}$ dark photoperiod. The females were used in different ways:

1. 22 females $(C L=39.9 \pm 4.3 \mathrm{~mm}$, weight $=21.0 \pm 6.6 \mathrm{~g})$ were used to estimate the correlation between egg count on the 3rd pair of pleopods and total fecundity. Eggs were stripped, weighed, counted and managed as described above for marbled crayfish.

2. 16 ovigerous females $(C L=40.0 \pm 5.0 \mathrm{~mm}$, weight $=20.8 \pm 7.0 \mathrm{~g}$ ) were used to test the ability of killer shrimp to destroy and eat signal crayfish hatchlings (juveniles in the 1st DS; Andrews 1907) directly from a female's pleopods in spite of maternal care and protection. Juveniles in the 1st DS were used because we observed low predation rates on signal crayfish eggs (see below). Prior to the experiment, all hatchlings from the 3rd pair of pleopods were carefully stripped from each female using entomological forceps and counted to estimate initial total fecundity.

3. 18 ovigerous females $(C L=41.5 \pm 4.1 \mathrm{~mm}$, weight $=23.3 \pm 6.3 \mathrm{~g}$ ) were incubated till hatched juveniles reached the 2nd DS - the stage of independence in astacid crayfish (Andrews 1907). Juveniles were carefully detached using entomological forceps and then used to testing of killer shrimp ability to overpower and eat signal crayfish early juveniles (see below an experimental set-up part). The sample of 50 juveniles in the 2nd DS was individually weighed using an analytical scale (Mettler, Toledo, USA) to the nearest $0.1 \mathrm{mg}$ to count the average individual weight $(22.5 \pm 2.9 \mathrm{mg})$.

4. For the last experiment, 70 randomly selected young mature signal crayfish (sex ratio $1: 1$, $\mathrm{CL}=30.5 \pm 2.7 \mathrm{~mm}$, weight $=8.1 \pm 2.2 \mathrm{~g}$ ) from the same source as females above were used for predation on mature killer shrimp individuals (see below an experimental set-up part).

\section{Experimental set-up}

\section{Killer shrimp as predators of unprotected crayfish eggs}

The feeding rates of killer shrimp (mean individual weight $65.5 \pm 28.1 \mathrm{mg}$ and $62.2 \pm 19.2 \mathrm{mg}$ in signal and marbled crayfish experiments, respectively) were quantified by using seven egg densities $(1,3,6,10,15,20$ and 25 eggs per 
experimental arena) with 8 replicates per each egg density and species. The experimental temperature was set at 15 and $20{ }^{\circ} \mathrm{C}$ for signal and marbled crayfish, respectively. $15{ }^{\circ} \mathrm{C}$ corresponds to the temperature at which signal crayfish can develop and hatch and $20{ }^{\circ} \mathrm{C}$ corresponds to the suitable temperature for marbled crayfish reproduction and the culture conditions of the experimental stock. The experiments were conducted in a Velp Scientifica-FOC 215e incubator with the light regime $12 \mathrm{~h}$ of light and $12 \mathrm{~h}$ of darkness. Boxes of $500 \mathrm{ml}$ volume (bottom area $7.5 \times 6 \mathrm{~cm}, 300 \mathrm{ml}$ of aged tap water) were used as experimental arenas. Stripped eggs were introduced in the experimental arenas $1 \mathrm{~h}$ before the experiment. One individual killer shrimp was then introduced to each arena. Each killer shrimp was starved for $24 \mathrm{~h}$ prior to the experiment to standardize hunger level. The number of remaining undamaged and damaged eggs (chopped) in each arena was recorded after $24 \mathrm{~h}$. In the case of eggs, no control stock without killer shrimp was made, because of the inactive nature of eggs.

We distinguished between eaten eggs $\left(N_{\mathrm{e}}\right)$, and damaged (chopped) eggs. We then analysed the effects of prey density and prey size (species). For prey species, a logistic regression between initial prey density $\left(N_{0}\right)$ and the proportion of prey eaten $\left(N_{\mathrm{e}} / N_{0}\right)$ was computed to identify the shape of the functional response:

$\frac{N_{e}}{N_{0}}=\frac{\exp \left(P_{0}+P_{1} N_{0}+P_{2} N_{0}^{2}+P_{3} N_{0}^{3}\right)}{1+\exp \left(P_{0}+P_{1} N_{0}+P_{2} N_{0}^{2}+P_{3} N_{0}^{3}\right)}$

where $P_{0}, P_{1}, P_{2}$, and $P_{3}$ are the intercept, linear, quadratic, and cubic coefficients, respectively, estimated by the maximum likelihood (Juliano 2001). If $P_{1}<0$, the proportion of prey killed declines monotonically with the initial density of prey, matching a type II functional response. If $P_{1}>0$ and $P_{2}<0$, the proportion of prey killed is a unimodal function of prey density, corresponding to a type III functional response (Juliano 2001). When our results indicated type II functional response we estimated functional response parameters using the type II Rogers random predator equation (Rogers 1972) that accounts for prey depletion during the experiment:

$N_{e}=N_{0}\left(1-\exp \left(-a\left(t-h N_{e}\right)\right)\right)$

where $N_{e}$ is number of prey eaten, $N_{0}$ is initial prey density per litre, $a$ is the consumer attack rate $\left(a, \mathrm{~L}_{\text {. day }}{ }^{-1}\right), h$ is the consumer handling time ( $h$, day.prey ${ }^{-1}$ ) and $t$ is the duration of experiment in days. Before fitting the Rogers model to our experimental data, we used Lambert $W$ function to solve Eq. 2 for $N_{e}$ (for further details see Bolker 2008).
$N_{e}=N_{0} \frac{W\left(a h N_{0} e^{-a\left(t-h N_{0}\right)}\right)}{a h}$.

We then tested whether the attack rate and handling time of each predator was influenced either by type of prey or predator species by comparing the overlap in the $95 \%$ confidence intervals $(\mathrm{CI})$ of the parameter estimated values. We assumed differences among treatment to be significant if CI of the parameter estimates did not overlap (Sentis et al. 2012, 2013). We calculated $95 \%$ CI using the standard errors for the estimates of each model parameter.

To determine the maximal number and biomass of eggs that killer shrimp are able to destroy or consume, we used the results from the three highest egg densities $(15,20,25$ eggs per arena), at which killer shrimp never killed or ate all the available prey. We calculated the average number of eaten prey, attacked prey (including eaten and attacked but not eaten prey together) and the biomass of prey eaten and expressed it as the percentage of individual predator body weight.

\section{Killer shrimp as predators of juvenile crayfish}

Functional response of killer shrimp (weight of $80.8 \pm 31.4 \mathrm{mg}$ and $87.1 \pm 31.0$ used for signal and marbled crayfish respectively) was quantified by measuring their feeding rate at seven densities of independent crayfish juveniles $(1,3,6,10,15,20$ and 25 juveniles per experimental arena) for each crayfish species. As in the egg experiment, two experimental temperatures were used $\left(15\right.$ and $\left.20^{\circ} \mathrm{C}\right)$ in accordance with the conditions experienced in the terminal stages of egg incubation and postembryonal development. Stripped independent juveniles (in the 2 nd and 3rd developmental stage for signal and marbled crayfish, respectively) were introduced to the experimental arenas one hour prior to predators. After this acclimation period, killer shrimps were released into the arenas. The number of remaining prey and dead prey in each arena was recorded after $24 \mathrm{~h}$. Nine and eight replicates were made for signal and marbled crayfish juveniles. In addition, replicates without consumers (five and three for signal and marbled crayfish, respectively) were conducted at each prey density to control for potential "natural" mortality of prey. We then used the same models as described above for crayfish eggs.

To determine the maximal number and biomass of juveniles that killer shrimp are able to destroy or consume, we again used the results from the three highest densities (15, 20,25 per arena) at which killer shrimp never killed or ate all the available prey. We calculated the average number of eaten prey, attacked prey (including eaten and attacked but not eaten prey together) and the biomass of prey eaten and 
expressed it as the percentage of individual predator body weight.

\section{Killer shrimp vs. ovigerous crayfish}

In total, 14 carrying females were tested per crayfish species. For marbled crayfish we used ovigerous females, while in signal crayfish we used females carrying 1st DS juveniles (Andrews 1907) since we found low predation of signal crayfish eggs in the previous set-up. As before, experiments were run at 15 and $20{ }^{\circ} \mathrm{C}$ for signal and marbled crayfish respectively, maintained by a Velp Scientifica-FOC $215 \mathrm{e}$ incubator with a regime of $12 \mathrm{~h}$ of light and $12 \mathrm{~h}$ of darkness. Boxes with a volume of $2500 \mathrm{ml}$ (bottom $25.4 \times 17.3 \mathrm{~cm}$, bottom area $0.044 \mathrm{~m}^{2}, 2000 \mathrm{ml}$ of aged tap water) with a shelter (halved ceramic plant pot) and gravel substrate were used as experimental arenas.

Before stocking the experimental arenas, all eggs/juveniles were stripped from the females' 3rd pair of pleopods and counted to estimate the initial total fecundity (see above) in both control and amphipod-exposed females. Seven females from each species were individually placed in arenas together with a stock of killer shrimps and, as a control, seven females were placed in arenas without killer shrimps. Killer shrimp stock consisted of 16 animals per arena (weight of $76.8 \pm 32.4 \mathrm{mg}$ and $81.5 \pm 26.7 \mathrm{mg}$ used for signal and marbled crayfish, respectively), equivalent to a density of $\sim 360$ individuals per $\mathrm{m}^{2}$. This corresponds with densities of killer shrimp found in natural conditions (e.g. MacNeil et al. 2010) but is much less than the highest recorded densities: 4000-10,000 individuals per square meter (Van Riel et al. 2006; Gallardo et al. 2012).

Experimental arenas were then placed in the incubators for $72 \mathrm{~h}$. After this period all females were removed and all eggs/juveniles were gently stripped from their pleopods and counted. The remaining killer shrimps in the experimental arena were also counted. The estimated initial fecundity was then compared with actual counts in control and amphipodexposed females.

\section{Crayfish as predators of killer shrimps}

Functional response of mature crayfish (both signal and marbled crayfish) was quantified by measuring their feeding rate at seven densities of mature killer shrimps $(1,3,6,10,15$, 20 and 25 killer shrimps per experimental arena). Individual killer shrimps had a mean weight of $95.4 \pm 26.4 \mathrm{mg}$ and $91.3 \pm 31.5 \mathrm{mg}$ for signal and marbled crayfish experiments, respectively. To account for small differences in crayfish body weight, the predator pressure on prey is expressed as number of prey eaten per gram of predator. The experimental temperature of $20{ }^{\circ} \mathrm{C}$ was used for both species, maintained by Velp Scientifica-FOC 215e incubator with light regime $12 \mathrm{~h}$ of light and $12 \mathrm{~h}$ of darkness. Killer shrimps were introduced to the experimental arenas one hour prior to consumers. After this acclimation period, crayfish were released into the arenas. The number of remaining prey and dead prey in each arena was recorded after $24 \mathrm{~h}$. Eight replicates of each density were made for both signal and marbled crayfish. In addition, three replicates without consumers were conducted for each prey density to control for potential "natural" mortality of prey. We then modelled functional response as described above.

To reveal the maximal numbers of prey and biomass which each crayfish species is able to destroy or eat, we used the results from the tests with the three highest densities of killer shrimp (15, 20, 25 per arena), in which crayfish never killed or ate all prey offered. We calculated the average number of eaten prey, attacked prey (including eaten and attacked but not eaten prey together) and the biomass of eaten prey and expressed it as a percentage of individual predator body weight.

\section{Statistical analyses}

The statistical analyses were conducted in $\mathrm{R}$ and Statistica 13. Analysis of functional response of organisms and their parameters was performed in R (R Core Team 2016). To compare differences in estimated and observed fecundity in both control and amphipod-exposed carrying females we used paired $t$ tests. A Mann Whitey non-parametric test was used to assess differences in estimated and observed fecundity between amphipod-exposed crayfish and the control group, and to test for differences in the relative biomass of prey eaten (relative to the individual predator biomass) by signal and marbled crayfish. For all the statistical test we used $\alpha=0.05$.

\section{Results}

\section{Killer shrimp as predators of crayfish eggs}

Only 10 of 54 killer shrimps were able to open and consume the eggs of signal crayfish, i.e., only $18.5 \%$ of individuals. These 10 killer shrimps were able to eat up to 2 eggs and damage 3 eggs (damaged uneaten eggs) at maximum, respectively. Damaged eggs were observed in all densities, eaten eggs only in densities $6,10,20$, and 25 . In all cases we observed the consumption of all egg-stalks, the connecting parts between the female pleopods and eggs. There was no relationship between prey density and number of prey eaten so the relationship was not investigated by functional response approach.

Only one killer shrimp from 54 (i.e. 1.9\%) did not damage and eat any marbled crayfish eggs (prey density 3 ). The 


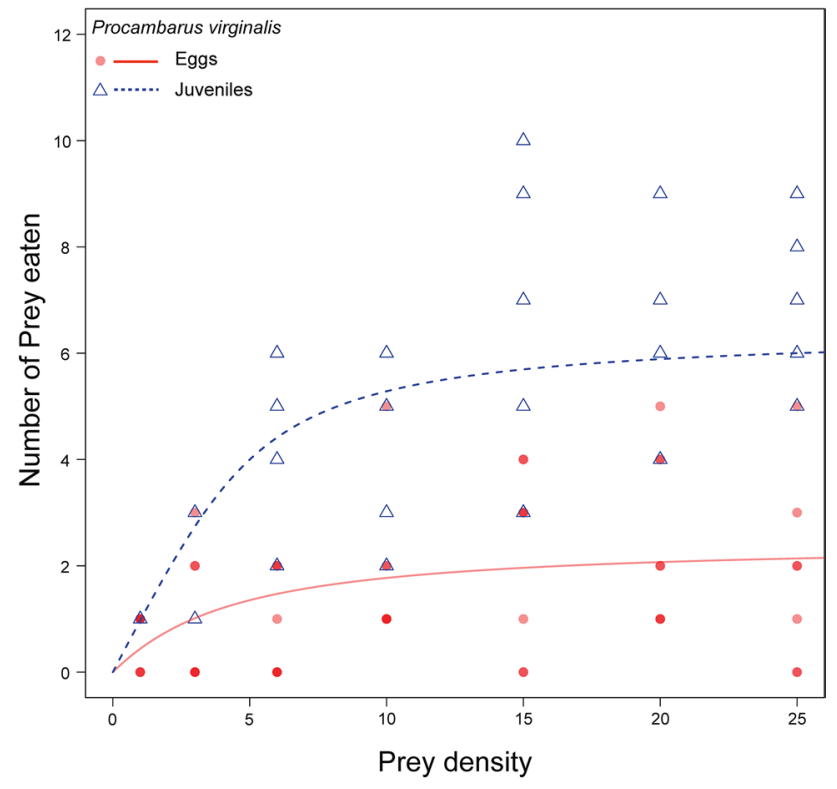

Fig. 1 Prey type dependent functional responses. Individual replicates $($ dots $=$ eggs, triangles $=$ juveniles $)$ overlaid by prediction of the most parsimonious model (full and dashed line). Red=eggs, blue $=$ juveniles

maximum amount of eggs consumed and damaged was 5 and 11 , respectively. The smallest killer shrimp that successfully damaged and even consumed the egg was equal to the size of the smallest killer shrimp used ( $35 \mathrm{mg}$ ). The functional response curve corresponded to the Holling type II $(\mathrm{P} 1=-4.03 ; \mathrm{SE}=1.07 ; P<0.001)$ (Fig. 1). Calculated attack rate and handling time are presented in Fig. 2 and Table 1. Those values indicate the lower effort to find and attack immobile prey but its more difficult handling.

At the three highest prey densities, the number of eaten marbled crayfish eggs and damaged eggs was significantly higher than that of signal crayfish (eaten eggs $Z=-3.50$, $P<10^{-3}$; damaged eggs $\left.\mathrm{Z}=-5.82, P<10^{-6}\right)$. There was no difference in the relative biomass eaten between the two species. The average number of eaten prey, attacked prey and the prey eaten biomass expressed as the percentage of predator body weight is shown in Table 2 .

\section{Killer shrimp as predators of crayfish juveniles}

Only 13 of 63 killer shrimps were able to predate on signal crayfish independent juveniles (2nd DS), i.e. only $20.6 \%$ of individuals. We therefore did not find a significant relationship between prey density and number of prey eaten, and did not calculate functional response. These 13 killer shrimps were able to eat up to 3 juveniles and kill 4 juveniles (killed and uneaten) at maximum, respectively. Eaten and/or killed juveniles were observed in all densities tested. The smallest

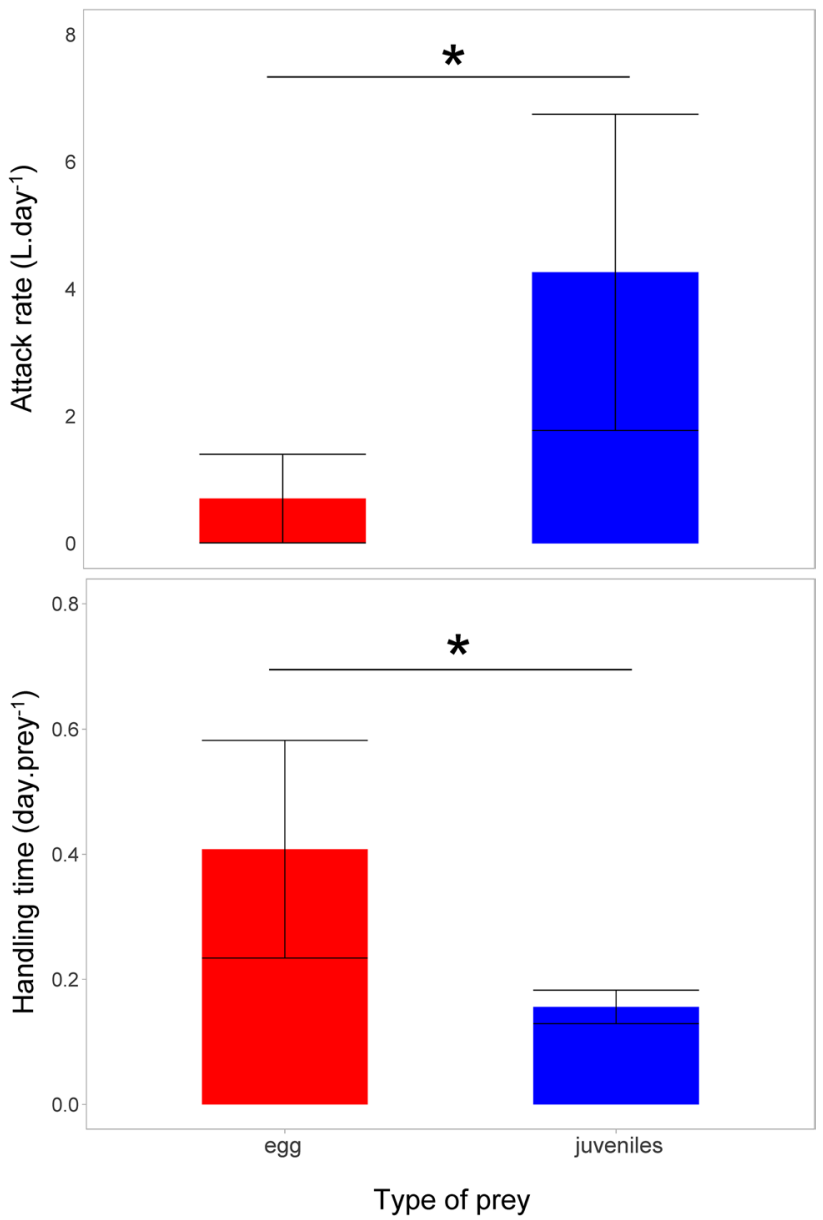

Fig. 2 Comparison of killer shrimp (Dikerogammarus villosus) attack rates and handling times between marbled crayfish (Procambarus virginalis) eggs and juveniles. Data shown as mean $\pm 95 \%$ confidence interval. Significant differences (revealed by comparing the overlap in the $95 \%$ confidence intervals (CI) of the parameter estimated values in accordance to Sentis et al. 2012, 2013) are marked by asterisk

Table 1 Handling time (h) and attack rate (a) of killer shrimp Dikerogammarus villosus preying on marbled crayfish (Procambarus virginalis) juveniles and eggs.

\begin{tabular}{|c|c|c|c|c|c|}
\hline & Estimate & SE & CI & Min & $\operatorname{Max}$ \\
\hline \multicolumn{6}{|c|}{ Marbled crayfish } \\
\hline \multicolumn{6}{|c|}{ Eggs } \\
\hline$a$ & 0.70 & 0.36 & 0.70 & 0.008 & 1.4 \\
\hline$h$ & 0.40 & 0.09 & 0.17 & 0.23 & 0.58 \\
\hline \multicolumn{6}{|c|}{ Juveniles } \\
\hline$a$ & 4.26 & 1.26 & 2.49 & 1.78 & 6.74 \\
\hline$h$ & 0.155 & 0.013 & 0.03 & 0.13 & 0.18 \\
\hline
\end{tabular}

Standard error of mean (SE), confidence interval (CI), minimal (Min) and maximal value (Max) 
Table 2 The number of prey eaten, prey killed (attacked but not eaten), and the weight of prey eaten expressed as a percentage of predator biomass in different predator-prey set-ups

\begin{tabular}{|c|c|c|c|c|c|c|c|}
\hline \multirow[t]{2}{*}{ Predator } & \multirow[t]{2}{*}{ Prey } & \multicolumn{2}{|l|}{ Prey eaten } & \multicolumn{2}{|l|}{ Prey killed } & \multicolumn{2}{|c|}{ Biomass eaten (\%) } \\
\hline & & Mean & Range & Mean & Range & Mean & Range \\
\hline $\mathrm{Dv}-15^{\circ} \mathrm{C}$ & Eggs-S & $0.6 \pm 0.8^{b}$ & $0-2$ & $1.0 \pm 1.1^{\mathrm{b}}$ & $0-3$ & $6.6 \pm 10.0^{\mathrm{a}}$ & $0-32.3$ \\
\hline $\mathrm{Dv}-20{ }^{\circ} \mathrm{C}$ & Eggs-M & $2.2 \pm 1.6^{\mathrm{a}}$ & $0-5$ & $7.8 \pm 1.7^{\mathrm{a}}$ & $3-11$ & $9.4 \pm 6.6^{\mathrm{a}}$ & $4.8-21.3$ \\
\hline $\mathrm{Dv}-15^{\circ} \mathrm{C}$ & Juv.-S & $0.3 \pm 0.7^{\mathrm{b}}$ & $0-3$ & $0.6 \pm 0.9^{b}$ & $0-4$ & $6.0 \pm 12.9^{b}$ & $0-45.2$ \\
\hline $\mathrm{Dv}-20^{\circ} \mathrm{C}$ & Juv.-M & $6.3 \pm 2.1^{\mathrm{a}}$ & $3-10$ & $9.3 \pm 2.3^{\mathrm{a}}$ & $4-13$ & $27.2 \pm 10.0^{\mathrm{a}}$ & $5.9-43.8$ \\
\hline $\mathrm{S}-20^{\circ} \mathrm{C}$ & Dv & $4.7 \pm 3.5^{\mathrm{a}}$ & $0-15$ & $7.7 \pm 5.1^{\mathrm{b}}$ & $0-21$ & $6.1 \pm 4.7^{\mathrm{b}}$ & $0-17.7$ \\
\hline $\mathrm{M}-20^{\circ} \mathrm{C}$ & Dv & $5.3 \pm 2.5^{\mathrm{a}}$ & $1-12$ & $13.1 \pm 6.4^{\mathrm{a}}$ & $3-23$ & $17.0 \pm 7.9^{\mathrm{a}}$ & $1.9-33.4$ \\
\hline
\end{tabular}

killer shrimp able to predate on signal crayfish independent juveniles weighed $47.7 \mathrm{mg}$.

All killer shrimps were able to kill and eat marbled crayfish independent juveniles (3rd DS). The maximum number of juveniles consumed and killed was 10 and 13, respectively. The minimal size of the killer shrimp that successfully killed and consumed an independent marbled crayfish juvenile was $38 \mathrm{mg}$ (at the density 10), equal to the size of the smallest killer shrimp used. The functional response curve corresponded to the Holling type II $(\mathrm{P} 1=-3.71, \mathrm{SE}=0.77$, $P<0.001)$ (Fig. 1). Calculated attack rate was significantly higher than on marbled crayfish eggs $(P<0.001)$ while handling time was significantly lower than on marbled crayfish eggs (see Fig. 2, Table 1).

At the three highest prey densities, killer shrimp ate significantly more marbled crayfish juveniles than signal crayfish juveniles $\left(\mathrm{Z}=-6.00, P<10^{-6}\right)$, killed more juveniles $\left(\mathrm{Z}=-6.03, P<10^{-6}\right)$ and consumed a greater biomass of marbled crayfish juveniles than signal crayfish juveniles $\left(\mathrm{Z}=-4.79 P<10^{-5}\right)$. The average number of eaten prey, attacked prey and the biomass eaten expressed as the percentage of predator body weight is shown in the Table 2 .

Killer shrimp (Dv; Dikerogammarus villosus), marbled crayfish (M; Procambarus virginalis), and signal crayfish (S; Pacifastacus leniusculus) were used as predators as well as prey. Juv.-crayfish juveniles in 2nd and 3rd developmental stage of signal (S) and marbled crayfish (M), respectively. Eggs-egg of signal (S) and marbled crayfish (M). Experiments were performed at $15{ }^{\circ} \mathrm{C}$ and $20{ }^{\circ} \mathrm{C}$ for signal and marbled crayfish eggs and juveniles respectively (prey densities 15, 20, and 25 individuals), according to their temperature specific incubation terminal phases

Different superscripts indicate significant differences within experimental set-ups $(\alpha=0.05)$. Data are presented as mean \pm standard deviation

\section{Killer shrimp vs. ovigerous crayfish}

A highly significant linear relationship was found between the egg number on the $3^{\text {rd }}$ pair of pleopods and overall fecundity in both signal crayfish $(\mathrm{y}=35.924+3.019 \mathrm{x}$, $\mathrm{R}^{2}=0.856, \quad P<10^{-6}$ ) and marbled crayfish $\left(\mathrm{y}=-9.730+3.431 \mathrm{x}, \mathrm{R}^{2}=0.937, P<10^{-6}\right)$. This linear relationship was used to estimate fecundity of control and amphipod-exposed females. Egg-carrying signal crayfish females stocked together with killer shrimp individuals had significantly lower final fecundity than estimated $\left(t=7.39, P<10^{-3}\right)$ while control females did not. The difference between estimated and observed fecundity was significantly higher in amphipod-exposed females than in control ones $(Z=2.30, P=0.021)$, on average $12.6 \%$ more juvenile losses than the control. While counting attached juveniles, some were found still attached to pleopods but missing substantial parts of their body (usually whole abdomen and part of the carapace).

Similarly to signal crayfish, marbled crayfish females stocked together with killer shrimp individuals had significantly lower fecundity than estimated $(t=3.79, P=0.009)$ while control females did not. The difference between estimated and observed fecundity was also significantly higher in amphipod-exposed females than in control ones $(\mathrm{Z}=2.68, P=0.007)$. It is in average $14.6 \%$ more juvenile

Table 3 The fecundity estimated (E) and observed (O), and the average difference $(\%)$ between estimated and observed values in carrying females of signal crayfish (S; Pacifastacus leniusculus) and marbled crayfish (M; Procambarus virginalis) when exposed to killer shrimp (Dv; Dikerogammarus villosus) and without killer shrimp presence [control (C]

\begin{tabular}{cccl}
\hline Species & Fecundity E & Fecundity O & $\begin{array}{l}\text { Difference } \\
\text { between E and } \\
\text { O }(\%)\end{array}$ \\
\hline S & & & \\
C & $133.4 \pm 16.1^{\mathrm{a}}$ & $122.1 \pm 23.7^{\mathrm{a}}$ & $-9.0 \pm 9.5^{\mathrm{A}}$ \\
Dv & $151.0 \pm 49.3^{\mathrm{a}}$ & $119.3 \pm 42.0^{\mathrm{b}}$ & $-21.6 \pm 6.6^{\mathrm{B}}$ \\
M & & & \\
C & $186.3 \pm 102.6^{\mathrm{a}}$ & $191.7 \pm 106.2^{\mathrm{a}}$ & $4.2 \pm 7.9^{\mathrm{A}}$ \\
Dv & $183.4 \pm 96.9^{\mathrm{a}}$ & $164.9 \pm 95.5^{\mathrm{b}}$ & $-10.4 \pm 6.6^{\mathrm{B}}$ \\
\hline
\end{tabular}

Significant differences $(\alpha=0.05)$ between estimated and observed values in particular rows are highlighted by lower case superscripts Significant difference in average differences between control and amphipod-exposed females in the last column are highlighted by upper case superscripts. Data are presented as mean \pm standard deviation 
losses compared to control. Estimated and observed fecundity and mean differences are presented in Table 3.

During exposure time females were able to substantially reduce the number of killer shrimps. Signal and marbled crayfish females killed on average $53.6 \pm 38.0 \%$ and $57.1 \pm 6.7 \%$ of stocked killer shrimps, respectively.

\section{Crayfish as predators of killer shrimps}

Signal crayfish used in the experiments were significantly larger $\left(t=16.09, P<10^{-6}\right)$ and heavier $\left(t=14.04, P<10^{-6}\right)$ than marbled crayfish. Signal crayfish were able to eat 15 (density 20) or kill 21 (density 25) killer shrimps (killed and uneaten) at maximum while marbled crayfish ate 12 (density 20) and killed 23 (density 25) killer shrimps at maximum. Thus, a ratio between crayfish weight and prey eaten was applied to account for crayfish size.

The functional response curve corresponded to the Holling type II for both signal crayfish $(\mathrm{P} 1=-4.99$, $\mathrm{SE}=1.73, P<0.001)$ and marbled crayfish $(\mathrm{P} 1=-4.29$, $\mathrm{SE}=1.14, P<0.001)($ Fig. 3$)$. Attack rate did not differ significantly between signal and marbled crayfish, while handling time was significantly lower in marbled crayfish than in signal crayfish (Fig. 4).

At the three highest prey densities, the number of eaten killer shrimps did not significantly differ between signal crayfish and marbled crayfish, but the number of killed

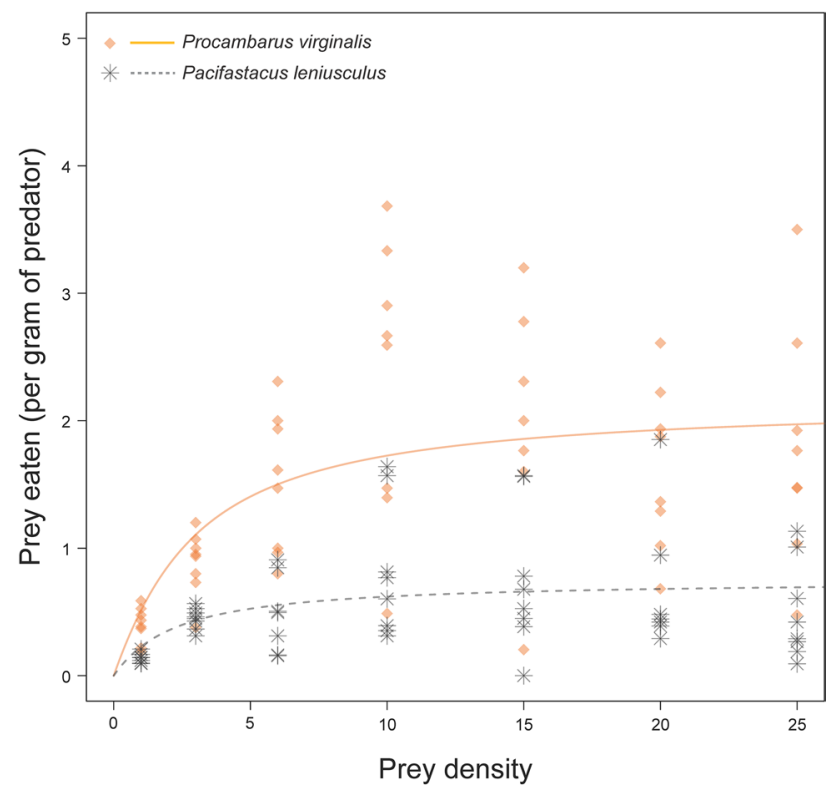

Fig. 3 Curves corresponding to Holling type II calculated for density dependent functional responses from single-consumer (signal crayfish Pacifastacus leniusculus and marbled crayfish Procambarus virginalis) preying on killer shrimp (Dikerogammarus villosus). Individual replicates (dots) overlaid by prediction of the most parsimonious model (dashed line)

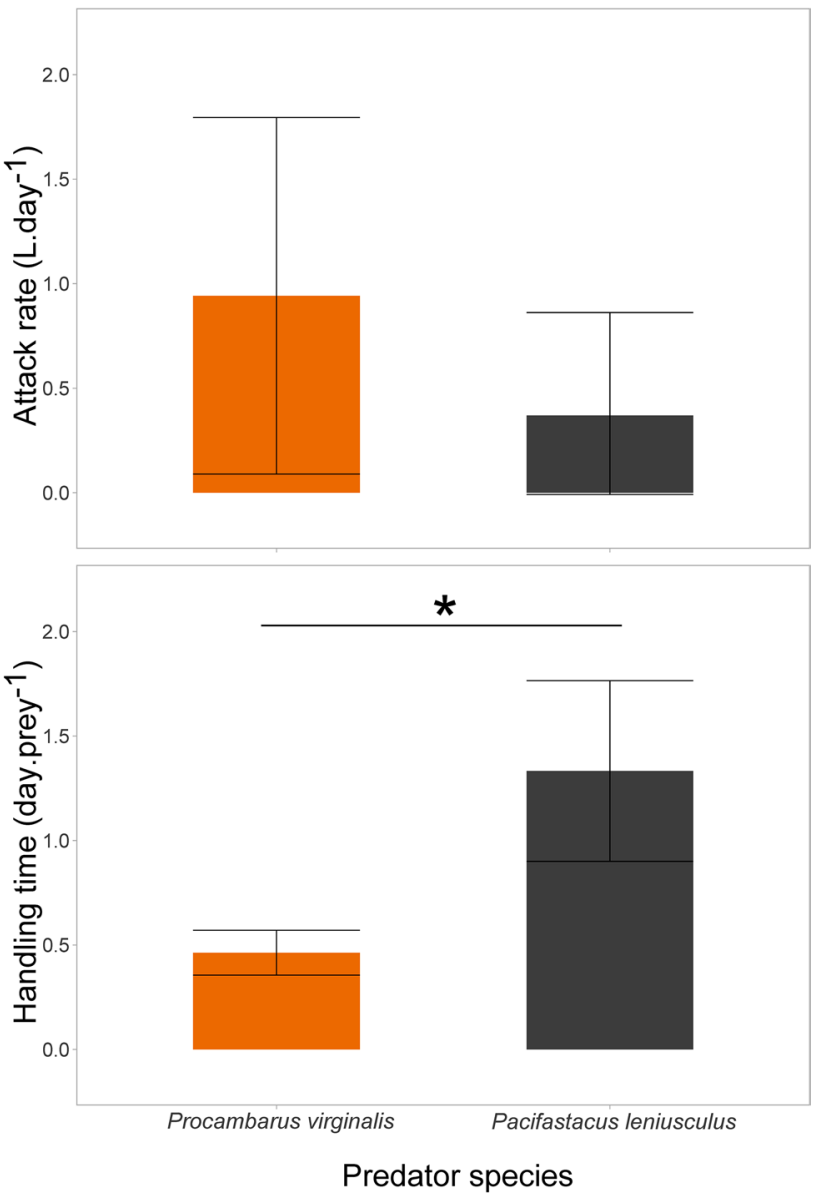

Fig. 4 Comparison between attack rate and handling time of signal crayfish (Pacifastacus leniusculus) $(\mathrm{n}=56)$ and marbled crayfish (Procambarus virginalis) $(\mathrm{n}=56)$ predating on killer shrimp (Dikerogammarus villosus). Data shown as mean $\pm 95 \%$ confidence interval. Significant differences (revealed by comparing the overlap in the $95 \%$ confidence intervals (CI) of the parameter estimated values in accordance to Sentis et al. 2012, 2013) are marked by asterisk

killer shrimps (i.e. eaten + killed and uneaten) was significantly higher in marbled crayfish $(\mathrm{Z}=-3.09, P=0.002)$, as well as the biomass eaten $\left(\mathrm{Z}=-4.35 P<10^{-4}\right)$. The average number of eaten prey, attacked prey and the biomass eaten expressed as percentage of predator body weight is shown in Table 2.

\section{Discussion}

As a result of multiple invasions, novel and often unexpected species compositions are reported with many effects on native biodiversity. Except the strong effect on native species, non-native invaders can also have an impact on other non-native invaders. These interactions are still not well studied. Killer shrimp co-exist and interact in many European rivers with invasive crayfish species. In the present 
study the example species included two invasive crayfish species: (1) signal crayfish representing family Astacidae and hence also partially European native crayfish potentially co-existing with killer shrimp, and (2) marbled crayfish representing family Cambaridae which differ from astacids, among others, by the smaller size of eggs and independent juveniles (Kozák et al. 2015). Crayfish, no matter from which family are characterised by intensive brood care and further maternal care even in stages when juveniles are freely moving, fully developed and independent (Aquiloni and Gherardi 2008; Mathews 2011; Vogt 2013).

During embryonal development crayfish clean the clutch and move by pleopods to prepare the best conditions for incubation. After hatching, the female's care continues during the stages of dependent juveniles-1st developmental stage in astacids and 1st and 2nd stage in cambarids (Vogt 2013; Kozák et al. 2015). In the following stages, juveniles become independent, actively feeding and moving in the proximity of the mother, but still use the mother's abdomen as a safe port in danger (Aquiloni and Gherardi 2008; Kubec et al. 2019). Egg clutches and early juveniles therefore seem to be well protected, but are they protected when exposed to strong killer shrimp pressure? As it known, killer shrimp is able to predate on independent cambarid juveniles till 4 th or even 5th developmental stage with a potential to reduce the crayfish offspring recruitment (Buřič et al. 2009) but can they predate on larger astacid juveniles or even predate on protected eggs and juveniles directly at the female's abdomen? The present study elaborated the influence of killer shrimp on incubated egg clutches and juveniles from the theoretical (predation on detached eggs/juveniles without guarding females) as well as practical point of view when carrying females were faced with the group of killer shrimps at a realistic field density more than 20 times lower than maximal reported values (Van Riel et al. 2006; Gallardo et al. 2012).

We found that killer shrimp can predate on both eggs and juveniles of both tested crayfish species, although the larger size of astacid eggs and juveniles as well as lower incubation temperature of eggs and thus lower metabolic activity of predators, may partially protect them. But the smaller sized cambarid eggs and first developmental stages were very good prey for killer shrimps, and were consumed in high quantities. The estimated attack rates and handling times indicated that killer shrimps are more efficient at (or prefer) catching juveniles than eggs. Also, shorter handling times indicate that they can consume more juveniles than eggs when their densities are not limited. Overall, it seems that killer shrimps feed more on juveniles than eggs which is a bit surprising. It may be that the nutritional quality of eggs is poor compared to juveniles, or killer shrimp may prefer moving prey. However, we suggest it is more likely that killer shrimps simply struggle to open the egg shell, increasing the handling time. Moreover, crayfish juveniles are more common, so amphipods are more "experienced" in handling them throughout evolution, while crayfish eggs are something rare in the environment because of their attachment to mother during incubation.

The biomass consumed by killer shrimp illustrates its high impact on invertebrate communities (Hellmann et al. 2017). We confirmed that killer shrimp kill more prey than they can eat (only $28 \%$ of and $68 \%$ of killed marbled crayfish eggs and juveniles were also consumed) as described also Dick and Platvoet (2000). In real conditions, where the clutches of eggs/juveniles are actively guarded and cared by females (Vogt 2013) this rate could differ. We decided to use ovigerous females because the vast majority of the time when females carry a clutch (eggs and first developmental stages of juveniles) consists of egg incubation (Reynolds 2002). But the limited ability of killer shrimp to open and eat big eggs of signal crayfish lead us to use females with fresh hatchlings i.e. juveniles in the $1^{\text {st }} \mathrm{DS}$, to see a possible effect of killer shrimps on the carried clutch. Carrying females of both species guarded their clutches which resulted in more than a $50 \%$ decrease of killer shrimp quantity during the experiment. However, clutches were not guarded effectively because females lost a significant proportion of their offspring (12\% of hatchlings in signal crayfish and $14 \%$ of eggs in marbled crayfish). In the case of signal crayfish, several halves of juveniles were observed among the surviving juveniles, further confirming the destructive impact of killer shrimp on the clutch. The effect of crayfish cannibalism can be ruled out here, because crayfish in the 1st developmental stage of crayfish do not feed yet (Reynolds 2002; Kozák et al. 2009). Some post-manipulation egg losses were observed in marbled crayfish, but these also occurred in the control group which was handled in the same way. Experiment was carried out in limited space which can in fact limit the effect of killer shrimp due to restricted possibilities to escape from the outreach of the crayfish. In natural conditions we suggest even higher clutch losses are likely in killer shrimp populated areas because of the unrestricted space and availability of sheltering spaces for killer shrimp to escape and hide (e.g. at the bottom of several layers of differently sized particles). In such conditions crayfish females have limited opportunities to catch the intruder or limit their overall quantities.

Killer shrimp also play an important role as prey species in European freshwater ecosystems (Gherardi 2007), and as expected both crayfish species we tested were able to prey on them at a considerable intensity. However, the difference between the two crayfish species predatory impact was significant. Despite the smaller size of marbled crayfish (about $74 \%$ and $45 \%$ of signal crayfish size and weight, respectively), it was able to eat equal numbers of killer shrimps. However, they killed almost twice the 
number of prey than signal crayfish did, much like other true predators that kill more than is possible to eat (Kruuk 1972; Oksanen et al. 1985; Veselý et al. 2017a, b). They also consumed almost three times the relative biomass eaten by signal crayfish. The much lower handling time of prey by marbled crayfish can help to explain these findings. In addition, they may have a higher metabolic rate at $20{ }^{\circ} \mathrm{C}$ as warm water species compared to cold water signal crayfish. Marbled crayfish have also been found to be more voracious and slower to reach satiation than spinycheek crayfish (Linzmaier and Jeschke 2019).

Overall, the results from our experiments confirmed the predatory capabilities of the killer shrimp and highlight their extreme boldness when attacking clutches of crayfish eggs or juveniles actively guarded by females. This bold predatory behavior illustrates the serious threat posed by killer shrimp invasions as well as the interesting foraging behavior of pilfering under the "safety camera". It is surprisingly risky behavior, given that crayfish females were were able to eat around $50 \%$ of killer shrimp in the experimental stock. Due to its intensive aggressive foraging on various aquatic organisms (Platvoet et al. 2009; MacNeil et al. 2013; Taylor and Dunn 2017) it is no wonder that killer shrimp trophic position is more similar to that of small benthic fish (Van Riel et al. 2006) or even to predatory fish (MacNeil et al. 2010) than to other gammarids. In addition to these direct trophic impacts, they are also strong competitors for resources such as shelters against predators (Van Riel et al. 2007; Platvoet et al. 2009). High population densities of killer shrimp can magnify these effects (Cuthbert et al. 2019) but also can provide a good food source for other aquatic organisms as fish (Gherardi 2007) or crayfish as confirmed by our study. In their early developmental stages marbled crayfish are vulnerable to being preyed upon by killer shrimp, but as adults the roles are reversed and they voraciously predate upon killer shrimp, killing more than they can eat (only consuming $\sim 40 \%$ of prey killed). Despite this reciprocal predation pressure these two invaders are probably not able to extinguish each other (e.g. due to other food resources) but they probably can negatively affect each other during long term coexistence.

Our results support the need for more complex investigation of over-invaded freshwater ecosystems, where communities accumulate new invasive species over time with an increasing number of interactions types and strength among them (Collin and Johnson 2014). In many large river systems native species are in the minority and in the case of benthic communities this situation is even worse. The ecosystems functioning therefore become changed as the influence of multiple invaders can be additive or even multiple (Ricciardi and Atkinson 2004; Penk et al. 2017). Our study provides further evidence that novel IAS have not only major ecological impacts (including predation on native species, increased competition for habitat and resources, disease transfer or habitat degradation) but can also theoretically inhibit, substitute or (in extreme cases) even extirpate each other.

Acknowledgements We also deeply appreciate the assistance of Nichola Plowman for language correcting of this manuscript.

Funding The study was financially supported by the Czech Science Foundation (project No. 19-04431S).

\section{Compliance with ethical standards}

Conflicts of interest The authors declare no competing financial interests.

Ethical statement The study did not involve endangered or protected species. All experimental manipulations were conducted according to the principles of the Institutional Animal Care and Use Committee (IACUC) of the University of South Bohemia, Faculty of Fisheries and Protection of Waters, Research Institute of Fish Culture and Hydrobiology, Vodňany, based on the EU harmonized animal welfare act of Czech Republic. The above mentioned Ethical Committee (IACUC) specifically approved this study. The principles of laboratory animal care and the national laws 246/1992 and regulations on animal welfare were followed (Ref. number 22761/2009-17210).

Open Access This article is licensed under a Creative Commons Attribution 4.0 International License, which permits use, sharing, adaptation, distribution and reproduction in any medium or format, as long as you give appropriate credit to the original author(s) and the source, provide a link to the Creative Commons licence, and indicate if changes were made. The images or other third party material in this article are included in the article's Creative Commons licence, unless indicated otherwise in a credit line to the material. If material is not included in the article's Creative Commons licence and your intended use is not permitted by statutory regulation or exceeds the permitted use, you will need to obtain permission directly from the copyright holder. To view a copy of this licence, visit http://creativecommons.org/licenses/by/4.0/.

\section{References}

Andrews EA (1907) The young of the crayfishes Astacus and Cambarus, vol 35. Smithsonian Institution, Washington https://doi. org/10.5962/bhl.title. 25870

Aquiloni L, Gherardi F (2008) Extended mother-offspring relationships in crayfish: the return behaviour of juvenile Procambarus clarkii. Ethology 114(10):946-954. https://doi.org/10.111 1/j.1439-0310.2008.01547.x

Bij de Vaate A, Jazdzewski K, Ketelaars HA, Gollasch S, Van der Velde G (2002) Geographical patterns in range extension of Ponto-Caspian macroinvertebrate species in Europe. Can J Fish Aquat Sci 59(7):1159-1174. https://doi.org/10.1139/f02-098

Boets P, Lock K, Messiaen M, Goethals PLM (2010) Combining data-driven methods and lab studies to analyse the ecology of Dikerogammarus villosus. Ecol Inf 5(2):133-139. https://doi. org/10.1016/j.ecoinf.2009.12.005 
Bolker BM (2008) Ecological models and data in R. Princeton University Press, Princeton

Buřič M, Kočí L, Petrusek A, Kouba A, Kozák P (2009) Invaders eating invaders: potential trophic interactions between the amphipod Dikerogammarus villosus and juvenile crayfish Orconectes limosus. Knowl Manag Aquat Ecosyst 394-395:05. https://doi. org $/ 10.1051 / \mathrm{kmae} / 2009015$

Buřič M, Kouba A, Kozák P (2013) Reproductive plasticity in freshwater invader: from long-term sperm storage to parthenogenesis. PLoS ONE 8(10):e77597. https://doi.org/10.1371/journ al.pone.0077597

Collin SB, Johnson LE (2014) Invasive species contribute to biotic resistance: negative effect of caprellid amphipods on an invasive tunicate. Biol Invasions 16(10):2209-2219. https://doi. org/10.1007/s10530-014-0659-4

Cuthbert RN, Dickey JWE, Coughlan NE, Joyce PWS, Dick JTA (2019) The Functional Response Ratio (FRR): advancing comparative metrics for predicting the ecological impacts of invasive alien species. Biol Invasions 21(8):2543-2547. https://doi. org/10.1007/s10530-019-02002-Z

Dick JTA, Platvoet D (2000) Invading predatory crustacean Dikerogammarus villosus eliminates both native and exotic species. Proc R Soc Lond B 267(1447):977-983. https://doi. org/10.1098/rspb.2000.1099

Dorn NJ, Wojdak JM (2004) The role of omnivorous crayfish in littoral communities. Oecologia 140(1):150-159. https://doi. org/10.1007/s00442-004-1548-9

Eggers T, Martens A (2001) A key to the freshwater Amphipoda (Crustacea) of Germany. Lauterbornia. 42(1):1-68

Gallardo B, Dodd J, Aldridge D (2012) A preliminary assessment of the impact of Dikerogammarus villosus on ecological status for the Water Framework Directive, Environment Agency, Bristol, UK

Gebauer R, Divíšek J, Buřič M, Večeřa M, Kouba A, Drozd B (2018) Distribution of alien animal species richness in the Czech Republic. Ecology and Evolution 8(9):4455-4464. https://doi. org/10.1002/ece3.4008

Gherardi F (2007) Biological invaders in inland waters: profiles, distribution, and threats. Springer Netherlands, Dordrecht https ://doi.org/10.1007/978-1-4020-6029-8

Hänfling B, Edwards F, Gherardi F (2011) Invasive alien Crustacea: dispersal, establishment, impact and control. Biocontrol 56(4):573-595. https://doi.org/10.1007/s10526-011-9380-8

Haubrock PJ, Kubec J, Veselý L, Buřič M, Tricarico E, Kouba A (2019) Water temperature as a hindrance, but not limiting factor for the survival of warm water invasive crayfish introduced in cold periods. J Great Lakes Res 45(4):788-794

Hellmann C, Schöll F, Worischka S, Becker J, Winkelmann C (2017) River-specific effects of the invasive amphipod Dikerogammarus villosus (Crustacea: Amphipoda) on benthic communities. Biol Invasions 19(1):381-398. https://doi.org/10.1007/ s10530-016-1286-Z

Holdich D, Reynolds J, Souty-Grosset C, Sibley P (2009) A review of the ever increasing threat to European crayfish from nonindigenous crayfish species. Knowl Manag Aquat Ecosyst 394395:11. https://doi.org/10.1051/kmae/2009025

Hossain MS, Patoka J, Kouba A, Buřič M (2018) Clonal crayfish as biological model: a review on marbled crayfish. Biologia 73(9):841-855. https://doi.org/10.2478/s11756-018-0098-2

Hossain MS, Kouba A, Buřič M (2019) Morphometry, size at maturity, and fecundity of marbled crayfish (Procambarus virginalis). Zool Anz 281:68-75. https://doi.org/10.1016/j. jcz.2019.06.005

Jeschke JM, Strayer DL (2005) From The Cover: invasion success of vertebrates in Europe and North America. Proc Natl Acad Sci 102(20):7198-7202. https://doi.org/10.1073/pnas.0501271102
Jeschke JM (2008) Across islands and continents, mammals are more successful invaders than birds. Divers Distrib 14(6):913-916. https://doi.org/10.1111/j.1472-4642.2008.00488.x

Jeschke J, Heger T (2018) Invasion biology: hypotheses and evidence, vol 9. CABI, Wallingfor https://doi.org/10.1079/9781780647 647.0000

Juliano S (2001) Non-linear curve fitting: predation and functional response curve. In: Scheiner SM, Gurevitch J (eds) Design and analysis of ecological experiment. Oxford University Press, New York, pp 178-196

Kotovska G, Khrystenko D, Patoka J, Kouba A (2016) East European crayfish stocks at risk: arrival of non-indigenous crayfish species. Knowl Manag Aquat Ecosyst 417:37. https://doi.org/10.1051/ $\mathrm{kmae} / 2016024$

Kouba A, Kanta J, Buřič M, Policar T, Kozák P (2010) The effect of water temperature on the number of moults and growth of juvenile noble crayfish, Astacus astacus (Linnaeus). Freshw Crayfish 17:37-41

Kouba A, Petrusek A, Kozák P (2014) Continental-wide distribution of crayfish species in Europe: update and maps. Knowl Manag Aquat Ecosyst 413:05. https://doi.org/10.1051/kmae/2014007

Kozák P, Buřič M, Kanta J, Kouba A, Hamr P, Policar T (2009) The effect of water temperature on the number of moults and growth of juvenile signal crayfish (Pacifastacus leniusculus) Dana. Czech J Anim Sci 54(6):286-292. https://doi.org/10.17221/1727-CJAS

Kozák P, Ďuriš Z, Petrusek A, Buřič M, Horká I, Kouba A, Kozubíková-Balcarová E, Policar T, Němečková K (2015) Crayfish biology and culture. University of South Bohemia in České Budějovice, Faculty of Fisheries and Protection of Waters

Krisp H, Maier G (2005) Consumption of macroinvertebrates by invasive and native gammarids: a comparison. J Limnol 64(1):55. https://doi.org/10.4081/jlimnol.2005.55

Kruuk H (1972) Surplus killing by carnivores. J Zool 166(2):233-244. https://doi.org/10.1111/j.1469-7998.1972.tb04087.x

Kubec J, Kouba A, Buřič M (2019) Communication, behaviour, and decision making in crayfish: a review. Zool Anz 278:28-37. https ://doi.org/10.1016/j.jcz.2018.10.009

Kulhanek SA, Ricciardi A, Leung B (2011) Is invasion history a useful tool for predicting the impacts of the world's worst aquatic invasive species? Ecol Appl 21(1):189-202. https://doi. org/10.1890/09-1452.1

Linzmaier SM, Jeschke JM (2019) Towards a mechanistic understanding of individual-level functional responses: Invasive crayfish as model organisms. Freshw Biol. https://doi.org/10.1111/fwb.13456

Lodge DM, Deines A, Gherardi F, Yeo DCJ, Arcella T, Baldridge AK, Barnes MA, Chadderton WL, Feder JL, Gantz CA, Howard GW, Jerde CL, Peters BW, Peters JA, Sargent LW, Turner CR, Wittmann ME, Zeng Y (2012) Global introductions of crayfishes: evaluating the impact of species invasions on ecosystem services. In: Futuyma D (ed), Annual review of ecology, evolution and systematics. annual review of ecology evolution and systematics, p 449, https://doi.org/10.1146/annurev-ecolsys-111511-103919

MacNeil C, Dick JT, Elwood RW (1997) The trophic ecology of freshwater Gammarus spp. (Crustacea: Amphipoda): problems and perspectives concerning the functional feeding group concept. Biol Rev Camb Philos Soc 72(3):349-364. https://doi. org/10.1017/S0006323196005038

MacNeil C, Platvoet D, Dick J, Fielding N, Constable A, Hall N, Aldridge D, Renals T, Diamond M (2010) The Ponto-Caspian 'killer shrimp', Dikerogammarus villosus (Sowinsky, 1894), invades the British Isles. Aquat Invasions 5(4):441-445. https:// doi.org/10.3391/ai.2010.5.4.15

MacNeil C, Boets P, Lock K, Goethals P (2013) Potential effects of the invasive 'killer shrimp' (Dikerogammarus villosus) on macroinvertebrate assemblages and biomonitoring indices. Freshw Biol 58(1):171-182. https://doi.org/10.1111/fwb.12048 
Mathews L (2011) Mother-offspring recognition and kin-preferential behaviour in the crayfish Orconectes limosus. Behaviour 148(1):71-87. https://doi.org/10.1163/000579510X548600

Oksanen T, Oksanen L, Fretwell SD (1985) Surplus killing in the hunting strategy of small predators. Am Nat 126(3):328-346. https:// doi.org/10.1086/284420

Patoka J, Buřič M, Kolář V, Bláha M, Petrtýl M, Franta P, Tropek R, Kalous L, Petrusek A, Kouba A (2016) Predictions of marbled crayfish establishment in conurbations fulfilled: Evidences from the Czech Republic. Biologia 71(12):1380-1385. https://doi. org/10.1515/biolog-2016-0164

Penk M, Saul WC, Dick JTA, Donohue I, Alexander ME, Linzmaier S, Jeschke JM (2017) A trophic interaction framework for identifying the invasive capacity of novel organisms. Methods Ecol Evol 8(12):1786-1794. https://doi.org/10.1111/2041-210X.12817

Platvoet D, Dick JTA, MacNeil C, van Riel MC, van der Velde G (2009) Invader-invader interactions in relation to environmental heterogeneity leads to zonation of two invasive amphipods, Dikerogammarus villosus (Sowinsky) and Gammarus tigrinus Sexton: amphipod pilot species project (AMPIS) report 6. Biol Invasions 11(9):2085-2093. https://doi.org/10.1007/s10530-009-9488-2

Pöckl M (2009) Success of the invasive Ponto-Caspian amphipod Dikerogammarus villosus by life history traits and reproductive capacity. Biol Invasions 11(9):2021-2041. https://doi. org/10.1007/s10530-009-9485-5

Rewicz T, Grabowski M, MacNeil C, Bącela-Spychalska K (2014) The profile of a 'perfect' invader - the case of killer shrimp, Dikerogammarus villosus. Aquat Invasions 9(3):267-288. https://doi. org/10.3391/ai.2014.9.3.04

Reynolds J (2002) Growth and reproduction. In: Holdich DM (ed) Biology of Freshwater Crayfish. London: Blackwell Science, pp 152-191

Ricciardi A, Atkinson SK (2004) Distinctiveness magnifies the impact of biological invaders in aquatic ecosystems. Ecol Lett 7(9):781784. https://doi.org/10.1111/j.1461-0248.2004.00642.x

Ricciardi A, Palmer ME, Yan ND (2011) Should biological invasions be managed as natural disasters? Bioscience 61(4):312-317. https ://doi.org/10.1525/bio.2011.61.4.11

Ricciardi A, Blackburn TM, Carlton JT, Dick JTA, Hulme PE, Iacarella JC, Jeschke JM, Liebhold AM, Lockwood JL, MacIsaac HJ, Pyšek P, Richardson DM, Ruiz GM, Simberloff D, Sutherland WJ, Wardle DA, Aldridge DC (2017) Invasion science: a horizon scan of emerging challenges and opportunities. Trends Ecol Evol 32(6):464-474. https://doi.org/10.1016/j.tree.2017.03.007

Rogers D (1972) Random search and insect population models. J Anim Ecol 41(2):369. https://doi.org/10.2307/3474

Sentis A, Lucas É, Vickery WL (2012) Prey Abundance, intraguild predators, ants and the optimal egg-laying strategy of a furtive predator. J Insect Behav 25(6):529-542. https://doi.org/10.1007/ s10905-012-9320-1

Sentis A, Hemptinne JL, Brodeur J (2013) How functional response and productivity modulate intraguild predation. Ecosphere. https ://doi.org/10.1890/ES12-00379.1

Simberloff D (2006) Invasional meltdown 6 years later: important phenomenon, unfortunate metaphor, or both? Ecol Lett 9(8):912-919. https://doi.org/10.1111/j.1461-0248.2006.00939.x

Strayer DL (2010) Alien species in fresh waters: Ecological effects, interactions with other stressors, and prospects for the future.
Freshw Biol 55(SUPPL. 1):152-174. https://doi.org/10.111 1/j.1365-2427.2009.02380.x

Svoboda J, Mrugała A, Kozubíková-Balcarová E, Petrusek A (2017) Hosts and transmission of the crayfish plague pathogen Aphanomyces astaci : a review. J Fish Dis 40(1):127-140. https://doi. org/10.1111/jfd.12472

Taylor NG, Dunn AM (2017) Size matters: predation of fish eggs and larvae by native and invasive amphipods. Biol Invasions 19(1):89107. https://doi.org/10.1007/s10530-016-1265-4

Väinölä R, Witt JDS, Grabowski M, Bradbury JH, Jazdzewski K, Sket B (2008) Global diversity of amphipods (Amphipoda; Crustacea) in freshwater. Hydrobiologia 595:241-255. https://doi. org/10.1007/s10750-007-9020-6

Van Riel MC, van der Velde G, Rajagopal S, Marguillier S, Dehairs F, Bij de Vaate A (2006) Trophic Relationships in the Rhine Food Web during Invasion and after Establishment of the Ponto-Caspian Invader Dikerogammarus villosus. Hydrobiologia 565(1):3958. https://doi.org/10.1007/s10750-005-1904-8

Van Riel MC, Healy EP, van der Velde G, Bij de Vaate A (2007) Interference competition among native and invader amphipods. Acta Oecologica 31(3):282-289. https://doi.org/10.1016/j.actao .2006 .12 .006

Veselý L, Buřič M, Kouba A (2015) Hardy exotics species in temperate zone: can "warm water" crayfish invaders establish regardless of low temperatures? Sci Rep 5(1):16340. https://doi.org/10.1038/ srep 16340

Veselý L, Boukal DS, Buřič M, Kozák P, Kouba A, Sentis A (2017) Effects of prey density, temperature and predator diversity on nonconsumptive predator-driven mortality in a freshwater food web. Sci Rep 7(1):18075. https://doi.org/10.1038/s41598-017-17998-4

Veselý L, Hrbek V, Kozák P, Buřič M, Sousa R, Kouba A (2017) Salinity tolerance of marbled crayfish Procambarus fallax $f$. virginalis. Knowl Manag Aquat Ecosyst. https://doi.org/10.1051/kmae/20170 14

Vodovsky N, Patoka J, Kouba A (2017) Ecosystem of Caspian Sea threatened by pet-traded non-indigenous crayfish. Biol Invasions 19(7):2207-2217. https://doi.org/10.1007/s10530-017-1433-1

Vogt G (2013) Abbreviation of larval development and extension of brood care as key features of the evolution of freshwater Decapoda. Biol Rev 88(1):81-116. https://doi.org/10.1111/j.1469185X.2012.00241.X

Vogt G, Tolley L, Scholtz G (2004) Life stages and reproductive components of the Marmorkrebs (marbled crayfish), the first parthenogenetic decapod crustacean. J Morphol 261(3):286-311. https ://doi.org/10.1002/jmor.10250

Weiperth A, Gál B, Kuř́ková P, Bláha M, Kouba A, Patoka J (2017) Cambarellus patzcuarensis in Hungary: the first dwarf crayfish established outside of North America. Biologia 72(12):15291532. https://doi.org/10.1515/biolog-2017-0159

Publisher's Note Springer Nature remains neutral with regard to jurisdictional claims in published maps and institutional affiliations. 